\title{
An Evaluation on Signature Knowledge and Awareness of Turkish Teacher Candidates
}

\author{
Ülker Şen ${ }^{1}$, Başak Uysal ${ }^{1}$ \\ ${ }^{1}$ Gazi Education Faculty, Gazi University, Ankara, Turkey \\ Correspondence: Ülker Şen, Department of Social Science and Turkish Education, Gazi Education Faculty, Gazi \\ University, Ankara, Turkey.
}

Received: August 29, 2016

Accepted: September 2, 2016

Online Published: September 8, 2016

doi:10.11114/jets.v4i11.1845

URL: http://dx.doi.org/10.11114/jets.v4i11.1845

\begin{abstract}
Signature is developed by individuals different from other biological traces such as DNA and fingerprint. The development of signing ability that takes place in the main heading of writing education, is under the responsibility of individuals, peers of individuals and teachers of individuals. The aim of this study is to evaluate the knowledge and awareness levels of the students in Turkish Teaching Department regarding the concept of literature. In this study in which the questionnaire model has been implemented, qualitative and quantitative data have been collected by means of Signature Knowledge and Awareness Form that was composed by the researchers. 298 students studying in Turkish teaching department participated in this study. The main results of the study are as follows: $65,4 \%$ of the teacher candidates who participated in the study did not receive information about signature in education level. $17,4 \%$ of the teacher candidates stated that their teachers guided them about signature formation process. Furthremore, $28,9 \%$ of the participants stated that they forged a signature in a period of their lives. It has been identified in the study that the most frequently used key words of the participants are the concepts such as approval, personal symbol, authenticity, representation and personal mark.
\end{abstract}

Keywords: signature, writing education, teacher education, Turkish language teaching, handwriting

\section{Introduction}

In 1894, France was faced with a lawsuit that would continue until $21^{\text {th }}$ century. A spying letter has been found in a military base in France without any signature. This letter resulted in a great indignation in the army and the commanders tried to identify the owner of this letter. As a result of the efforts made, handwriting experts concluded that this letter belonged to Lieutenant Alfred Dreyfus. Although Dreyfus claimed that he is innocent, he was arrested and got the death penalty. This spying history that is still discussed today, has been strictly defended by Emile Zola and paved the way for the appearance of the book, which enabled the writer to be famous, named "The Dreyfus Event".

According to the results of the lawsuit, the hero Dreyfus was called as a justice warrior and the most determinant factor of this lawsuit was the handwriting. Handwriting as a biological identity indicator according to Quaiao and Xing (2016). Therefore, handwriting is one of the identity evidences that is submitted by individuals to the external world just like fingerprint or DNA.

According to Baltacioğlu, writing is the human being itself (Baltacioğlu, 1941). Stylistic features, spaces between words, spaces between lines, slope of the letters in the writings that are written by handwriting, inform us about the personal information of the owner of the writing. Similarly, the signature is the reflection of its owner. Characteristic features that can be identified with writing reveal more specificially in the signature that is written with handwriting. Signature is also symbol of the legal responsibility of individuals.

According to Sevim (2002), signature is a private mark that symbolizes the identity of individuals, and that represents the rights and obligations of individuals upon various documents (Sevim, 2002). Sayıc1 (2009) defines the signature as an entity that obligates the owner of the signature under debt or commitment and that generates legal or criminal consequences, and it has sanctions (Say1c1, 2009). Bafra (2001) states that the signature is used in order to fulfill the duties of accepting and verifying. Accordingly, signature is a distinctive mark that obligates the owner of the signature under a receivable or debt (Bafra, 2001). According to another definition, signature means writing the name, surname or the first letter of name specifically by individuals (Artut and Demir, 2007). 
Mutual points are written below according to the definitions of the researchers from various disciplines:

- Signature is a handwriting product.

- Signature is personal and distinctive.

- Signature is an indication of right and obligation in legal transactions.

- Signature has the characteristic of a final word that is written in a text.

Legal system and positive sciences agreed on the fact that the signature requires responsibility for individuals. Although the signature is determinant on identity just like DNA or fingerprint, it is not an inborn ability different from DNA and fingerprint. When human being which is a social creature firstly faces with the obligation of signing, a process of forming a private mark for themselves begins. Therefore, individuals necessarily encounter the process of signature formation process officially or unofficially.

\subsection{Signature Education}

The learning process of signature that has legal, psychological, artistic and educational dimensions is conducted sometimes by formal education institutions and sometimes by social comparisons made.

Learning of writing occurs by means of strong-willed acquisition instead of trial and error. The simplest way of strong-willed acquisition is the imitation of the sample perceived (Birincioğlu and Özkara, 2010). According to Evrim and Okan (1976) if individuals adhere to stereotypes, the improvement of their personalities are prevented (Evrim and Okan, 1976). With this expression, they declared that a direct imitation of the sample perceived cannot reflect the personal features. Therefore, with respect to signature formation, it is possible to mention the factors beyond taking someone as model.

According to Sarıyldiz (2013), even though the first lines in individuals lives are called only as drawing, the period of time until school life is quite important in terms of identifying the writing style of individuals (Sarıyldız, 2013). Writing skill is taught in Turkish courses. Therefore, signature teaching should also be evaluated within the scope of Turkish courses.

The following acquisitions that take part inTurkish Writing Program $\left(6^{\text {th }}-7^{\text {th }}-8^{\text {th }}\right.$ grades $)$, are about recognition and usability of signature: "Signing in accordance with the rules (MEB, 2002), signing on the page that was edited in accordance with the rules (MEB, 2002), signing a homework completed in accordance with the rules (MEB, 2002)."

In the previous Turkish Course ( $1^{\text {th }} 5^{\text {th }}$ grades), which was before the Turkish Course that entered into force in 2015 and that is still valid, the acquisition of "They sign and know its meaning (MEB, 2009)." takes part but this program has been annulled with the Turkish Course $\left(1^{\text {th }}-8^{\text {th }}\right.$ grades $)$ Curriculum that was accepted in 2015. In the relevant program, although the acquisitions regarding the writing teaching take part in writing skill, any acquisition has not been included in the program regarding the signature skill. It is possible to state that the students who will be subjected to this program can only imitate the perceived samples as stated by Birincioğlu and Özkara (2010) and can improve the drawings as stated by Sariyıldız (2013) in order to have the signature skill and to improve this skill. Artut and Demir (2007) stated that most of the people in Turkey put signature by drawing meaningless images and this view also supports this circumstance.

Examining the studies in literature about signature and handwriting, it can be observed that the studies have been conducted in miscellaneous disciplines. Since the examination of signature and document relates to very different discipline subjects, it cannot be collected under one single academic structure (Yalçın and Gürbüz, 2010). On the other hand, the key word of "handwriting" should be included in the study as a key word as well as the examination of signature and document in order to tackle the literature with in a larger extent.

It should be stated that the person who conducted the first studies in literature about signature is A. S. Osborn who is actually a teacher. Osborn (1910), presented material-based samples about signature diversifications, the analysis and identification of handwriting in his study named Questioned Documents (Osborn, 1910). This book is also accepted to be the first book that examined the forensic texts (Alkan et al., 1998). After these studies were conducted, signature science has been taken for examination in Turkey as well based on law. Alkan (1996) has one of the important studies conducted in the field of forensic sciences. Alkan (1996) conducted a study in order to identify whether the individuals' signatures change when they get old, and he compared the data obtained in terms of various writing parameters. As a result of the study, it has been identified that the changes can be observed on signatures depending on aging (Alkan, 1996).

Sevim (2002) has another study that deals with forensic sciences. Sevim (2002) tried to identify which features of the individuals' signatures changed and which features did not as a result of the fact that they put their signature with claim of innocence. As a result of the study, it has been concluded that the owner of the signature cannot be identified when individuals put signature with the claim of innocence or with forged signature and that a limited opinion can be notified about a part of them and that the most of them successfully changed their signatures (Sevim, 2002). 
Sayıc1 (2009) conducted a questionnaire about the awareness of signature concept and signature obligation towards the individuals living in Turkey. He also included the signature and signature obligations in Turkish legal system in his study based on trial reports and expert reports (Sayıc1, 2009).

Arslan (2001) examined the curriculums of the department of graphic design in the faculty of fine arts within the scope of her study and she received the expert opinions and implemented a visual perception test on the senior students at undergraduate programs in 95 different occupational groups. As a result of her study, she concluded that the students graduated from the department of graphic design in the faculty of fine arts might be useful in forensic-purpose handwriting and especially in the examinations of writing and signature (Arslan, 2001).

Ataç et al. (2012) conducted a study about the ownership of handwriting belongs to individuals. They determined the greatest two problems in this field as the lack of field experts and lack of material (Ataç et al., 2012).

Uğurlu et al. (2010) conducted another study aiming at the trend line in the recognition of signature and handwriting. Thanks to the structure suggested, it is possible for the individuals to make an assumption on the profile of the owners of the handwritings based on the slopes of writing styles (Uğurlu et al., 2010).

Uysal and Altunbay (2016) utilized the data that were collected from 600 primary school students within the context of their study that aims to identify the signature knowledges of primary school students. The data obtained as a result of the study, revealed the necessity of tackling the signature skill as an acquisition especially in Turkish language teaching courses (Uysal and Altunbay, 2016).

Having examined the above mentioned studies with their general lines, it is observed that there is not any study regarding the teaching of signature skill. The following expressions need to be taken into consideration about writing skill that takes part in Turkish Language Teaching Program when education of signature skill is evaluated within writing skill: With the development of writing skill via Turkish Course Curriculum, it has been aimed to enable the students to describe their emotions, thoughts, dreams, designs, impressions, their views and dissertations on a certain subjects by utilizing the opportunities of language in accordance with the rules of written expression; to enable them to get into the habit of writing as a way of expressing themselves and to enable the students who have the ability of writing to improve their skills (MEB, 2015).

In this regard, it is possible to state that Turkish language teachers are directly responsible for developing the writing skill. However, when it comes to signature skill, it is a necessity to be aware of the knowledge and awareness levels of teacher candidates. With this objective, the aim of this study is to evaluate the signature knowledge and awareness levels of Turkish language teacher candidates. The answers have been sought for the following questions based on general objective.

1. What is the distribution of education level at which the participant teacher candidates received signature knowledge?

2. Which courses did the participant teacher candidates take about signature knowledge?

3. What is the definition of signature according to the participant teacher candidates?

4. Who are the person/people guided to the participant teacher candidates while forming their signatures?

5. What is the knowledge status of the participant teacher candidates with respect to the usage of signature?

6. What is the status of the participant teacher candidates about putting signature (forged signature) on behalf of someone else?

\section{Method}

This study that has been conducted with the purpose of identifying the knowledge and awareness levels of Turkish language teacher candidates about signature, is a questionnaire model study since it aimed to reveal an existing circumstance. Questionnaire model study aims to collect the data in order to identify the certain features of a group (Büyüköztürk et al., 2010).

\subsection{Study Group}

The population of the study is composed of $1^{\text {th }}, 2^{\text {nd }}, 3^{\text {rd }}$ and $4^{\text {th }}$ grade students, who studied at Gazi University, department of Turkish language teaching in the faculty of education 2015-2016, that were randomly picked via easily accessible circumstance sampling. The features of the working group is demonstrated in Table 1.

Table 1. Gender distribution of the students who participated in the study

\begin{tabular}{lll}
\hline Gender & $\mathrm{N}$ & $\%$ \\
\hline Female & 222 & 74,5 \\
Male & 76 & 25,5 \\
Total & 298 & 100,0 \\
\hline
\end{tabular}


As it can be understood from the table, $74,5 \%$ of the participant students are female and $25,5 \%$ of the participant students are male. There are 372 students registered in the department of Turkish Language Teaching, Faculty of Education in Gazi University as of 2016 (OIBS, 2016). In this regard, it is possible to state that the most of these students have been reached in the study. The continuing class distribution of the participant students are demonstrated in Table 2.

Table 2. Class distribution of the students who participated in the study

\begin{tabular}{lll}
\hline Class & $\mathrm{N}$ & $\%$ \\
\hline 1 & 71 & 23,8 \\
2 & 65 & 21,8 \\
3 & 75 & 25,2 \\
4 & 87 & 29,2 \\
Total & 298 & 100,0 \\
\hline
\end{tabular}

71 students at $1^{\text {th }}$ grade, 65 students at $2^{\text {nd }}$ grade, 87 students from $3^{\text {rd }}$ garde and 87 students at $4^{\text {th }}$ grade participated in the study. Considering the percental distribution, it can be observed that there is an equal distribution between classes on the basis of participation.

\subsection{The Collection and Analysis of the Data}

"Personal Information Form" has not been used in the study since any demographic information was not collected apart from the class and gender variables of university students in the study group. Instead of forms, these two items have been written under the heading of "Personal Information" just below the questionnaire reply directive.

The knowledge and awareness levels of Turkish language teacher candidates in the study group about signature, have been collected by means of "Signature Knowledge and Awareness Form" composed of 8 articles that was composed by the researchers.

A wide literature review has been made before Signature Knowledge and Awareness Form has been composed within the scope of the questions such as "What is signature?", "How a signature should be?" "Is signature education or signature teaching is provided in education levels?", "What is the role of signature in teaching programs?" and "What is the responsibility of Turkish course teacher in signature teaching?" The questionnaire items have been determined by utilizing the literature review made.

A database has been composed based on the questionnaire items determined. The survey form has been prepared after the items in the database have been arranged in harmony. Pre-questionnaire form has been evaluated by three field experts. As a result the evaluations, the items that were thought not to be in compliance with the objective of the study, have been removed. Then, the spelling errors, punctuation errors and wrong expressions that were identified by the experts, have been corrected.

Pre-application has been performed on 15 students ( 4 students at $1^{\text {th }}$ grade, 3 students at $2^{\text {nd }}$ grade, 4 students at $3^{\text {rd }}$ grade and 4 students at $4^{\text {th }}$ grade) by means of questionnaire form that was shaped in accordance with expert views.

The form has been finalized after pre-application. The form is composed of a total of 9 questions including open-ended (interpretation) and closed-ended (ordering, filter). The implementation time of the form is approximately 15 minutes.

The forms have been implemented by the researchers by means of face to face interview method. The information concerning the implementation of forms and the objective of the study have been told by the researchers before the implementation. Then, questionnaire forms have been distributed to the students. The researchers remained in the classroom during the implementation. The questionnaire forms replied have been collected by the researchers again.

307 questionnaire forms have been obtained after the implementation. 298 of 307 questionnaire forms have been taken into evaluation. 9 questionnaire forms have been excluded from the evaluation since they were filled deficiently.

SPSS 21 (Statistical Packages for Social Science) package program has been used in the analysis of the data obtained from the questionnaires. Frequency, percentage and average have been used in descriptive analysis. Descriptive analysis and content analysis have been conducted in the analysis of open-ended questions.

In the analysis of qualitative data, the researchers made evaluation in the capacity of coder. Qualitative data analysis made the results quantitative and enabled the numbers and key words to represent each other.

The researchers coded the key words independently from each other. Then, they compounded the data and composed categories and the template. Template study has been conducted again every two weeks with the purpose of ensuring the internal reliability of coders. Inter-coders reliability has been found as $90 \%$ according to the formula of Miles and Huberman (1994). Circumstances and concepts on which an entire unanimity was not built, have been tackled in the last meeting and an entire cosensus has been built on the key words with the participation of a third coder who is an expert in the field. 


\section{Findings}

\subsection{What is the Education Level at Which the Participant Students Received the Signature Knowledge?}

Table 3. Education level at which the participant students received the signature knowledge

\begin{tabular}{lll}
\hline Degree & $\mathrm{N}$ & $\%$ \\
\hline Primary School & 9 & 3,0 \\
Secondary School & 23 & 7,7 \\
High School & 13 & 4,4 \\
University & 58 & 19,5 \\
Never & 195 & 65,4 \\
Total & 298 & 100,0 \\
\hline
\end{tabular}

As shown in the table, $65,4 \%$ of the students who participated in the study did not receive any information about signature at any education level. Universities are ranked the first place with 19,5\% among the education levels received by the students about signature knowledge. On the other hand, primary schools are ranked in the last place with $3 \%$ among the education levels received by the students about signature knowledge.

\subsection{What Are the Courses of the Participant Students that Provided Knowledge about Signature?}

With the purpose of identifying the knowledge of the participants about signature, the question of "Which courses has provided knowledge about signature yourself?" has been directed to the participants and the Table 4 is demonstrated below that is composed of the key words recorded in the answers obtained.

Having examined Table 4, it has been identified that the results are in consistent with Table 3. Most of the teacher candidates stated they received education about signature at university level.

According to the table, the participant students acquired the signature knowledge in Turkish courses (primary school, secondary school), writing education courses (university), writing techniques courses (university).

Table 4. Courses of the participant students that provided knowledge about signature

\begin{tabular}{lll}
\hline Course & Number of People & Degree \\
\hline Knowledge and Theory on Literature & 2 & University \\
Painting & 1 & High School \\
Written Expression & 4 & University \\
Language and Expression & 3 & High School, University \\
Turkish & 31 & Primary School, Secondary \\
& & School \\
History & 1 & High School \\
Elocution and Calligraphy & 2 & High School \\
Writing Techniques & 7 & University \\
Visual Arts & 3 & University \\
Social Sciences & 1 & University \\
Science of Life & 2 & Secondary School \\
Writing Course & 29 & University \\
Scientific Research Methods & 1 & University \\
Material Design & 2 & University \\
Learning Education & 1 & University \\
Citizenship & 1 & Secondary School \\
Ottoman Turkish & 1 & University \\
\hline
\end{tabular}

\subsection{What is the Definition of Signature According to the Students Who Participated in the Study?}

With the purpose of identifying the knowledge of the participants about signature, the question of "Please write down what is signature?" has been directed to the participants and the diagram is demonstrated below that is composed of the key words recorded in the answers obtained. 


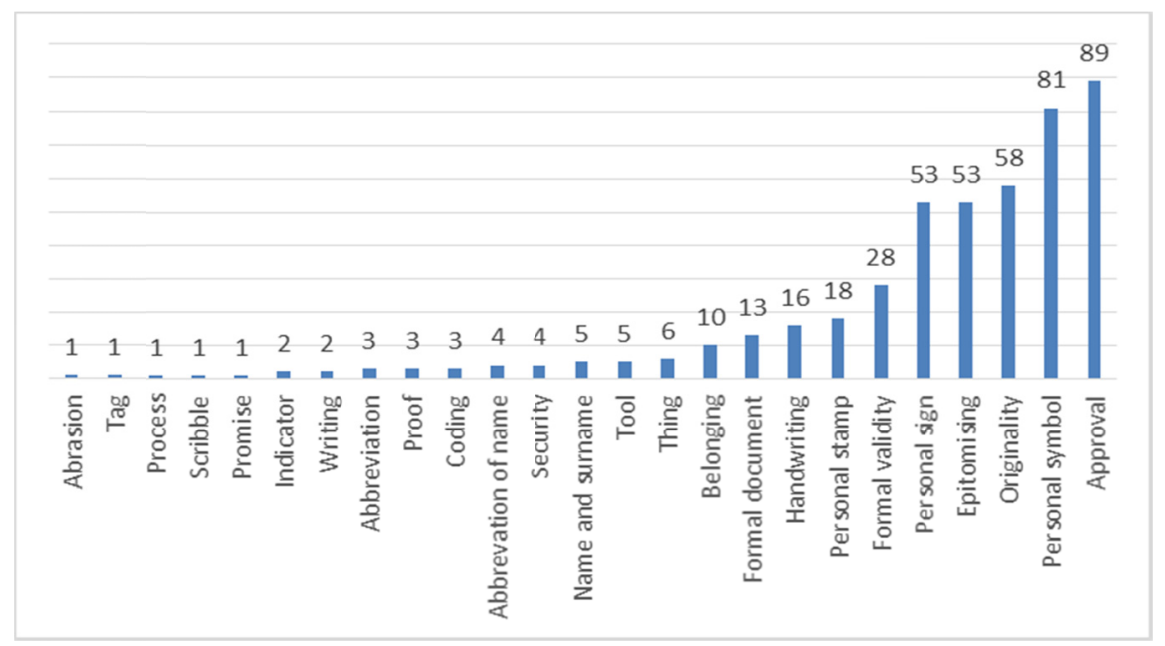

Diagram 1. Distribution of the key words stated by the participants in the description of signature

According to the diagram, it has been revealed that the most frequently used key words of the participants are the concepts such as approval, personal symbol, authenticity, representation and personal mark:

The mark that is used by the individual on an official document (P20)

Personalized approval and certification symbol (P256)

Indicator demonstrating the approval of an individual (P23)

Personal mark of an individual (P22)

Mark symbolizing the name and surname of an individual (P58)

It means the security of an individual on documents, incidents and circumstances (P198)

Official validity of signature has been brought into foreground in the definitions made by 27 teacher candidates:

Personal writing to confirm the legal documents (P200)

A form representing the indiviudal in legal affairs (P65)

Individual stamp feature of the signature has been preferred as a key word by 18 of the participants:

Seal of an individual (P15)

Personal stamp (P18)

16 people described the signature as the handwriting of an individual:

Writing the name and surname explicitly (P288)

An object indicating an approval via handwriting (P115)

Personalized writing of name and surname (P112)

3.4 Who Are the Person/People Guided to the Participant Students While Forming Their Signatures?

With the purpose of identifying the people who guided the participant students while forming their signatures, the question of "Who guided you while forming your signature?" has been directed to the participant students and the results are demonstrated in Table 5.

Table 5. People who guided the participant students while forming their signatures

\begin{tabular}{lll}
\hline Guide Person & $\mathrm{N}$ & $\%$ \\
\hline No one & 180 & 60,4 \\
Teacher & 52 & 17,4 \\
Father & 32 & 10,7 \\
Sibling & 9 & 3,0 \\
Mother & 9 & 3,0 \\
Friend & 8 & 2,7 \\
Other & 8 & 2,7 \\
Total & 298 & 100,0 \\
\hline
\end{tabular}


According to the table, it has been understood that the teachers are determinant authority about guidance $(\% 17,4)$. Father, mother, sibling and friend followed the student. $60,4 \%$ of the students declared that they did not receive support from anyone while forming their signatures.

\subsection{What Is the Signature Knowledge Status of the Teacher Candidates?}

9 questions have been addressed to the students in order to reveal this sub-problem. The students were asked to evaluate the given expressions as true or false. The data concerning the answers of the students are indicated below.

Table 6. Distribution of the propositions and answers presented to the teacher candidates

\begin{tabular}{|c|c|c|c|c|}
\hline Proposition & True & $\%$ & False & $\%$ \\
\hline Signature can be put with a lead pencil. & 38 & 12,8 & 260 & 87,2 \\
\hline $\begin{array}{l}\text { Signing on behalf of someone else does not require any legal obligation for } \\
\text { the person who puts the signature. }\end{array}$ & 288 & 96,6 & 10 & 3,4 \\
\hline Signature is put on name and surname. & 196 & 65,8 & 102 & 34,2 \\
\hline Signature can be put with pens apart from the ones that are black or blue. & 33 & 11,1 & 265 & 88,9 \\
\hline $\begin{array}{l}\text { Signature by procuration ('Vekaleten imza' in Turkish) means writing "v" } \\
\text { next to the name and surname of the principal (person who gives the } \\
\text { procuration) and writing the name and surname of the owner of the } \\
\text { signature and putting a signature the document. }\end{array}$ & 142 & 47,7 & 156 & 52,3 \\
\hline $\begin{array}{l}\text { The seal used in administrative affairs has also the characteristics of } \\
\text { signature. }\end{array}$ & 133 & 44,6 & 165 & 55,4 \\
\hline $\begin{array}{l}\text { Signing on behalf of someone ('Yerine imza' in Turkish) means writing the } \\
\text { "y" next to the name and surname of the signature owner and putting a } \\
\text { signature that is similar to the genuine signature owner. }\end{array}$ & 55 & 18,5 & 243 & 81,5 \\
\hline
\end{tabular}

With respect to the expression of "Signature can be put with a lead pencil." that is a true proposition, $87,2 \%$ of the participants replied as "false" whereas $12,8 \%$ of the participants replied as "true". Concerning the expression of "Signing on behalf of someone else does not require any legal obligation for the person who puts the signature." that is a false proposition, 96,6\% of the participants replied as "true" whereas 3,4\% of the participants replied as"false". Regarding the expression of "Signature is put on name and surname." that is a true proposition, 65,8\% of the participants replied as "true". In concern with the expression of "Signature can be put with pens apart from the ones that are black or blue." that is a true proposition, $88,9 \%$ of the students replied as "false" whereas $11,1 \%$ of them replied as "true". With regard to the expression of "Signature by procuration ('Vekaleten imza' in Turkish) writing "v" next to the name and surname of the principal and writing the name and surname of the owner of the signature and putting a signature the document." that is a true proposition, $52,3 \%$ of the students replied as "true". With respect to the expression of "The seal used in administrative affairs has also the characteristics of signature." that is a false proposition, 55,4\% of the students replied as "false". Concerning the expression of "Signing on behalf of someone ('Yerine imza' in Turkish) means writing the "y" next to the name and surname of the signature owner and putting a signature that is similar to the genuine signature owner." that is a false proposition, $81,5 \%$ of the students replied as "true".

3.6 What Is the Status of the Participant Teacher Candidates about Putting Signature (Forged Signature) on Behalf of Someone Else?

The question of "Have you ever put a forged signature on behalf of someone else?" has been addressed to the teacher candidates with the purpose of identifying whether they had put a forged signatuer or not, and the results obtained are demonstrated in Table 7.

Table 7. Status of the participant teacher candidates about putting signature on behalf of someone else

\begin{tabular}{lll}
\hline & $\mathrm{N}$ & $\%$ \\
\hline Yes & 86 & 28,9 \\
No & 211 & 70,8 \\
Blank & 1 & 3 \\
Total & 298 & 100,0 \\
\hline
\end{tabular}

As indicated in the table, 86 students forged a signature on behalf of someone else. 211 of the participants declared that they did not forge a signature on behalf of someone else.

\section{Conclusion and Discussion}

$65,4 \%$ of the participants who participated in the study stated that they did not receive any education about signature at any education level in their lives. According to the results of the study conducted by Uysal and Altunbay (2016) on primary school students, it has been understood that $71 \%$ of the participant students did not receive any education about signature. This circumstance can be regarded as the deficient part of curriculums since primary school to high school. It is not possible to expect individuals to form their signature instinctively. Signature requires certain rules just like writing which facilitates to reach an agreement, ensures the unity and enables to have an aesthetic perspective. Therefore, the 
subjects such as where and how a signature should be put, need to be taught.

Another result obtained in the study is the fact that only $3 \%$ of the participants received information about signature in primary school whereas $7,7 \%$ of them received information in secondary school and $4,4 \%$ of them received information in high school. This data can be interpreted in such a way that most of the participants (approximately 85\%) did not receive any information about signature until the age of eighteen. Having regard to the fact that the responsbility of signing starts much earlier than university education, it is possible to declare that the teacher candidates encounter an education after responsibility and implementation. According to the study conducted by Say1c1 (2009), 41 (37,27\%) of the participants stated that they have knowledge on legal arrangements about signature whereas $69(62.73 \%)$ of them stated that they are not aware of the information on legal arrangements about signature. Considering the fact that the study population of Sayic1 (2009) reflects the overall mass of society sociodemographically, it has been revealed that Turkish language teacher candidates did not any other signature knowledge that may be different from this population.

When individuals start the primary schol, they become a member of a larger social group rather than a member of a small social group. In other words, socializing process increasingly continues since primary school education. Society also imposes certain responsibilities to individuals with socializing. An individual who reaches the age of eighteen needs to have legal responsibilities as well as social responsibilities. Individuals undertake tens of legal responsibilities such as banking transactions, job application, marriage, university enrollment, heritage and family law transactions by using their signatures. The study revealed a contradiction from this aspect. Individuals sign certain documents at the age of eighteen and they undertake major responsibilities. However, they do not know what a signature means and how to put a signature.

When it comes to the concept given by the participants in defining the signature, it is obvious that the participants generally have knowledge and awareness about the definition of signature. The signature features defined by the participants are the fact that signature is a handwriting product, that signature has a personal distinctiveness and it is an indicator of right and responsibility. However, when the individual-based definitions are examined, it is a remarkable circumstance that the teacher candidates tackle the signature from only one aspect in their definitions of signature. Most of the teacher candidates wrote short expressions such as "Signature is an approval.", "Signature is a symbol." and "Signature is a mark." in the space allocated for the relevant question in the form. The definitions of the teacher candidates remained insufficient when they were compared with the definitions in the literature.

According to the data given in Diagram 1, it is observed that the participants think differently in their expressions on how to put a signature. The participants demonstrated independent explanations from each other such as signature means writing name and surname, signature means writing only the name or signature means the abbreviation of name and surname. According to a study conducted by Sayıc1 (2009), it has been identified that 34 (32.08\%) of the individuals put their signature by writing their names and/or surnames, and that the rest 72 individuals (67.92\%) do not put their signature by writing their names and/or surnames (Say1c1, 2009). In accordance with the 2nd article of numbered 2525 Surname Act, "Real name is used in the beginning and surname is used in the last of expressions, writings and signatures (Surname Act, 1934)." Despite this act, there is not any unity about the elements of signature in functioning.

It has been determined that $65,4 \%$ of the teacher candidates who participated in the study stated that they did not receive any information about signature in education institutions whereas $34,6 \%$ of them declared that they received education about signature in education institutions. This circumstance points out the importance of identifying where these people of $34,6 \%$ received this information at which courses. This is because this deductions will give clues both to teachers, to those who prepare the curriculum and to lecturers. Important deductions have been made in the study about this subject as well. According to the data, the teacher candidates who participated in the study stated that they acquired the information about signature mostly in Turkish course (primary school, secondary school) in writing course (university) and in writing techniques (university). In this way, the importance of signature in Turkish language teaching and the responsibility of Turkish language teachers about signature education emerged automatically. Turkish courses in primary school and secondary school; writing course and writing techniques in university; are the courses in which the signature knowledge can be provided. It can be suggested that the subject of signature knowledge needs to be included in the curriculums of universities within the scope of the courses of instructors who give writing course and writing techniques. Furthermore, it can also be suggested that there is a necessity that the acquisitions related to signature need to be included in Turkish course curriculums (primary school/secondary school).

Considering the status of participants' taking someone as a guide, it has been identified that $60,4 \%$ of the participants did not receive any guidance service about signature knowledge. Although this circumstance does not entirely overlap with the expression of Birincioğlu and Özkara (2010) "Writing learning is accomplished by means of strong-willed acquisition instead of trial and error.", it can be interpreted in such a way that forming a signature without sample or guide can enable to reflect the character traits. The fact that $60,4 \%$ of the participants did not receive any assistance about forming a signature, overlaps the fact that $65,4 \%$ of the participants did not receive any knowledge about signature at any education 
level. Moreover, the participants mostly received assistance from their teachers while forming a signature and this circumstance demonstrates that the teachers play a significant role about this subject. Fathers are the most dominant guides in the families about the assistance received on forming a signature when intrafamilial situation is evaluated.

The following results have been obtained about the signature knowledge of the participants: $87,2 \%$ of the students replied the question of "Signature can be put with a lead pencil." as "false". Most of the teacher candidates stated that the signature cannot be put with a lead pencil. According to the literature, it is observed that putting a signature with a lead pencil is legally valid. On the other hand, there is an expression of "signature that will be put by handwriting is put with a pen/pencil that will not vanish and that will be imprinted to the letter (Official Gazette, 2015)." in Regulation on Procedures and Principles to be Implemented in Official Correspondences. It has been stated that a pencil should not be preferred while signing since it is open to forgery due to the chemical feature of pencil and since its permanence feature is insufficient. Is should also be considered that the exams such as KPSS (Public Personnel Selection Examination), YDS (Foreign Language Exam) and ALES (Academic Personnel and Postgraduate Education Entrance Exam) require the test takers to use lead pencil. $87,2 \%$ of the teacher candidates think that putting a signature with a pencil is invalid although they used pencil while putting a signature on very important exams of their lives that enabled them to get their existing titles.

$\% 50$ of the primary school students in the study of Uysal and Altunbay (2016) stated that the proposition of "Signature can be put with a pencil" is false. The usage of pencil in in-course activities and exams led to the rate to be high.

$88,9 \%$ of the students replied the expression of "Signature can be put with pens apart from the ones that are black or blue." as "false". Similar confusion took place in the issue of which colour of pen/pencil should be preferred while putting a signature similar to the issue of pen or pencil should be preferred while putting a signature. There is a consensus on the view that the colour of pen should be blue (ballpoint or pilot pen) while putting a signature on legal documents. Black-colour pens (ballpoint or pilot pen) are not preferred since they lead to a hesitation about the authenticity of the document (the suspicion may arise whether the document is photocopy or not). Putting a signature with black or blue pens is preferred whereas putting a signature with colourful pens (especially for legal documents) is not deemed to be appropriate by the participants of the study. Putting a signature with red pen is only valid/necessary in military correspondences. There is not any expression or suggestion about the colour to be used while putting a signature in "Regulation on Procedures and Principles in Official Correspondences" that was published in the Official Gazette. In this circumstance, in-house operation case laws come to the forefront. The teacher candidates are aware of the rule that it is not possible to put a signature with colourful pens rather than black and blue.

$96,6 \%$ of the students replied the expression of "Signing on behalf of someone else does not require any legal obligation for the person who puts the signature." as "true". Accordingly, the teacher candidates think that they will not undertake any responsbility when they put a signature on behalf of someone else. In case of duly signing on behalf of someone, the person who puts the signature on behalf of somone else shall legal undertake the reponsbility of the person whom she/he puts signature on behalf of. The person who does not duly put signature on behalf of someone else, shall be responsible legally in terms of both unduly signature and signing on behalf of someone else. The teacher candidates have a great fallacy about the subject.

Another element about this subject is the imitativeness of signature. The less complicated and developed a signature is, the easier it is to forge it. Therefore, it is possible to prevent the forgery by having a unique signature style (Aydoğdu and Ataç, 2011).

$65,8 \%$ of the students replied the expression of "Signature is put on name and surname." as "true". As it was expressed before, the signature should be put above the expression of "Name and Surname" in a way that it will not block "Name and Surname" part. This circumstance has legally gained vailidity with Regulation on Procedures and Principles to be Implemented in Official Gazette whose decree number is 2014/7074. 65,8\% of the teacher candidates truly know the fact that they need to put the signature above "Name and Surname" part.

$52,3 \%$ of the students replied the expression of "Signature by procuration ('Vekaleten imza' in Turkish) writing "v" next to the name and surname of the principal and writing the name and surname of the owner of the signature and putting a signature the document." as "true". The process of signature by procuration has been explained in the relevant bylaw as follows: "When a document is signed by procuration, the name and surname of the signer is written on the first line, principal authority is written in the second line as "Deputy of Prime Minister", "Deputy of Undersecretariat", "Deputy of Governor", "Deputy of Mayor", or "Deputy of Rector". The title of the principal before the power of attorney is not included (Official Gazette, 2015)." Therefore, signature by procuration means putting a signature on behalf of an authority but not an individual. However, $52,3 \%$ of the participants thought that their answer, which is individual-based proposition, is true but they gave the wrong answer.

$81,5 \%$ of the students replied the expression of "Signing on behalf of someone ('Yerine imza' in Turkish) means 
"writing the "y" next to the name and surname of the signature owner and putting a signature that is similar to the genuine signature owner" as "true". "When the document is signed by principal (person who gives the procuration) instead of the officer, the name and surname of the signer is written on the first line, the authority of the principal is written on the second line as "On behalf of Prime Minister", "On behalf of Governor" and "On behalf of Rector" and the title of signer authority is written on the third line (Official Gazette, 2015)". Similar to the signature by procuration, the representation of an institution is the point in question here but not an individual. Therefore, it is not possible for this proposition to be true. The remarkable expression in the proposition is "putting a signature similar to the signature owner". $81,5 \%$ of the participants replied this proposition as "true" and this demonstrates the participants have a deficient knowledge about legal dimensions of signature as well as the technical information about signature.

$28,9 \%$ of the participants declared that they had put signature (forged signature) on behalf of someone else. It can be concluded that the individuals whose signatures were copied by such participants did not have distinctive signature styles. In other words, the signatures of these people whose signatures were copied, are easily imitable and easy drawings. Therefore, putting a forged signature is not difficult for the person who puts a signature on behalf of someone else.

Forged signature is one of the most frequently encountered forgery types in Turkey. This is mostly because the signature is not subjected to a certain system or rule in Turkey (Öksüz, 1986). Rather than such system or rule in Turkey, the results of this study points out the fact that the participants of this study do not perceive putting a similar signature on behalf of someone else as a crime element.

$55,4 \%$ of the students replied the expression of The seal used in administrative affairs has also the characteristics of signature." as "false". Seal is described in Turkish Dictionary as "Tool or stamp that is composed of metal or rubber etc. on which the name or title of the relevant person or institution is written reversely" and "The name printed with this tool that can be used instead of signature" (Turkish Language Association, 2016) Thus, 55,4\% of the participants interpreted this proposition as false according to the definition of Turkish Language Association. In accordance with the 75th article of Notary Public Act, "The relevant individuals can use a seal if available in case they are not able to put signature or they are not able to use a hand signal that can be used instead of signature. In case they use seal, they are required to put their finger as well." (2010/9 Circular, 2010). The following provision has been presented in the same circular, in order not to encounter any irrecoverable circumstance in the future: People who issue the documents at public institutions should not use any mark or seal apart from the signatures that they put with their own handwriting. In this circumstance, it can be understood that approximately the half of the teacher candidates gave the wrong answer. As it is seen, the explanation in Turkish Dictionary does not overlap the provision in the Circular.

\section{On Behalf Of Conclusion}

Alfred Dreyfus who was referred in the beginning of the study, was innocent and he was just a victim of mistake of a grapholog, in other words, of a handwriting expert. 12 years after the finalization of the death sentence, the real criminal confessed his crime and Dreyfus became free. As stated by Chomsky, "It is the responsibility of intellectuals to speak the truth and expose lies (Chomsky, 1936)." This quote reminds the quote of "Writing is human being itself" by Baltacioğlu. Therefore, it is an obvious fact that the Turkish teachers who are responsible for improving the skills of handwriting and signature need to receive a technical information about this subject.

\section{References}

Alkan, N. (1996). Yaşlanmaya bağll yazı ve imza değişiklikleri, MA Thesis, İstanbul Üniversitesi, İstanbul Tıp Fakültesi Adli Tip Ana Bilim Dalı, Istanbul.

Alkan, N., Sözen, Ş., \& Kurtaş, Ö. (1998). Dünyada adli belge incelemesi. Adli Tip Bülteni, 3(2), 61-66.

Arslan, N. (2001). Adli amaçlı el yazısı ve imza incelemelerinde güzel sanatların yeri ve önemi. Gazi Üniversitesi, Sosyal Bilimler Enstitüsü, Yayımlanmamış Yüksek Lisans Tezi, Ankara.

Artut, K., \& Demir, H. (2007). Güzel yazı teknikleri ve öğretimi. Ankara: Anı Yayıncılık.

Ataç, Y., Aydoğdu, E., \& Bora, T. (2012). Adli bilimlerde el yazsının kişiye aidiyetinini tespiti. Polis Bilimleri Dergisi, 14(4).

Aydoğdu, E., \& Ataç, Y. (2011). Types of Signature Forgery, Detection and Prevention. Turkish Journal of Police Studies, 3(2), 49-73.

Bafra, J. (2001). İmza incelemeleri ve bilirkişilik. İstanbul Barosu Dergisi, 75(2), 356-365.

Baltacıoğlu, İ. H. (1941). Grafoloji Nedir?. İlköğretim Dergisi, 5(90), 115-118.

Birincioğlu, İ., \& Özkara, E. (2010). Adli belge incelemelerinde bilinmeyenler, örneklerle yazı ve imza analizi ile sslak imza kavramı. TBB Dergisi, 87, 403-433. 
Büyüköztürk, Ş. et al. (2010). Bilimsel araştirma yöntemleri, Ankara: Pegem Akademi Yayınları.

Chomsky, N. (1967). The responsibility of intellectuals. The New York Review of Books, 8(3).

Evrim, S., \& Okan, A. A. (1976). Hukuk ve psikoloji açısından imza ve el yazısı. Matbaa-13. İstanbul.

MEB, (2002). Türkçe Yazı Programı 6-7-8. Ankara: Millı̂ Eğitim Basımevi.

MEB. (2015). Türkçe Dersi (1-8. Sinıflar) Öğretim Programı. Ankara: Devlet Kitapları Basımevi.

MEB. (2019). Türkçe Dersi (1-5. Sinıflar) Öğretim Programı. Ankara: Devlet Kitapları Basımevi.

Miles, M. B., \& Huberman, A. M. (1994). Qualitative data analysis. London: Sage Publication.

Official Gazette. (2015). Retrieved from http://www.resmigazete.gov.tr/eskiler/2004/12/20041202.htm\#3. August 10, 2016.

OIBS, (2016). Retrieved from https://ogrenci.gazi.edu.tr/July 2, 2016.

Öksüz, A. (1986). Kişilerin kimliğini tespit etmede polise yardımcı olan imza ve parmak izinin tetkiki ve parmak izinin tasnifi. Kısmet Matbaası. Ankara.

Qiao, Y., \& Xing, L. (2016). DeepWriter: a multi-stream deep CNN for text-independent writer identification. CoRR, abs/1606.06472.

Sarıyıldız, A. (2013). El yazısı bilimi (grafoloji)'nin Türkçe eğitimi açısından önemi. TSA, 17(2), 83-88.

Sayıcı, B. (2009). Türkiye'de hukuk ve adli bilimler açısından imza ve karşılaşılan sorunlar. İstanbul Üniversitesi Adli Tıp Enstitüsü, Yayımlanmamış Yüksek Lisans Tezi, İstanbul.

Sevim, M. (2002). Adli imza incelemelerinde kişisel sapmaların belirlenmesi ve inkâr kastıyla atılan imzaların incelenmesi. Ankara Üniversitesi Sağlık Bilimleri Enstitüsü, Yayımlanmamış Yüksek Lisans Tezi, Ankara.

Surname Act. (1934). Retrieved from http://www.mevzuat.gov.tr/MevzuatMetin/1.3.2525.pdf. August 4, 2016.

Turkish Language Association, (2016). Signature. Retrieved from www.tdk.gov.tr. July 2, 2016.

Uğurlu, B., Kaçan, K., \& Türkyılmaz, İ. (2010). Bilgi güvenliğinde el yazısı. Akademik Bilişsim'10 - XII. Akademik Bilişim Konferansı Bildirileri 10-12 Şubat 2010 Muğla Üniversitesi. 505-510

Uysal, B., \& Altunbay, M. (2016). A research on signature knowledge of the primary education students. International Journal of Languages' Education and Teaching, 4(2), 15-26.

Yalcin, N., \& Gürbüz, F. (2010). Islak imza kavramı, imza sahteciliği ve sslak imza konusunda Türkiye'de yapılan akademik çalışmalar, Akademik Bilişsim Konferansı, Anadolu Üniversitesi, Eskişehir.

This work is licensed under a Creative Commons Attribution 3.0 License. 